\title{
Phenotypic and genetic characterization of fowl pox and turkey pox viruses
}

\author{
Olfat E. Nakhla ${ }^{*}$, Y. A. Soliman ${ }^{2}$, M. M. Taha ${ }^{2}$ \\ ${ }^{1}$ Veterinary Serum and Vaccine Research Institute, Abbasia, Cairo and ${ }^{2}$ Central Laboratory for \\ Evaluation of Veterinary Biologics, Abbasia, Cairo, Egypt.
}

\begin{abstract}
Fowl and turkey pox viruses were analyzed for their heterogeneity on the basis of protein profile, western blotting, PCR analysis and restriction endonuclease analysis. On the protein level, only a single band with a WM of 115KDa was seen with turkey pox virus but not with the fowl strain, and a band reacted at 10KDa with Turkey but not fowl pox virus in western blotting analysis other protein profiles were nearly the similar. PCR amplification of the lateral terminal repeat (LTR) region of both viruses confirmed a single band migrating about 900 bp with both strains and restriction digestion proved the homology between both strains.
\end{abstract}

Fowl pox is a viral disease of poultry due to infection with avipoxvirus from the family Poxviridae. There is a number of pox viruses which affect different species of birds. Fowls and turkeys are particularly susceptible to fowl pox virus while pigeons suffer mostly from pigeon pox virus.

Turkeys are also frequently affected with poxvirus infection. The pox disease in turkeys have attracted attention as this disease has been reported worldwide, resulted into severe economic losses in spite of proper management and health care (Dash et al., 2003; Tripathy and Reed, 1989). This disease causes severe diptheritic and cutaneous lesions leading to high mortality in case of diptheritic form and appreciable economic losses in case of cutaneous form of disease due to meet condemnation (Tripathy and Reed, 1997). Pox infection in turkeys tends to be more chronic in nature with longer duration than fowl pox virus (Wakenell et al., 2001).

Virions consist of an envelope, a surface membrane, a core, and lateral bodies. During their life cycle, virions produce extracellular and intracellular particles that can occur in two phenotypes; may be enveloped during their extracellular phase. The infection is initiated by extracellular virions. Virus may be sequestered within inclusion bodies that are not occluded and typically contain one nucleocapsid (Boulanger et al., 2000). Virus capsid is enveloped and Virions mature naturally by budding through the

* Corresponding author. Tel.: +20 0106500618 ; E-mail address: dryousefadel@gmail.com (Yousef A. Soliman). membrane of the host cell. Virions are generally brick-shaped, or pleomorphic and measure200 $\mathrm{nm}$ in diameter, or 260-280 $\mathrm{nm}$ in diameter; 330$350 \mathrm{~nm}$ in length displaying tubular units. The core is biconcave with two lateral bodies. Lateral bodies are lens-shaped, nested between the core membranes, or between the surface membranes that contains a folded nucleoprotein thread.

Consistent with their size and complex structure, poxvirus virions contain numerous polypeptides. About 30 prominent bands are readily resolved by one-dimensional polyacrylamide gel electrophoresis of the membrane fraction of the virus which have been purified from infected cells and disrupted with sodium dodecyl sulfate and a reducing agent, but 75 or more are detected on two-dimensional gels (Jensen et al., 1996) or by mass spectrometry (Chung et al., 200). About 25 polypeptides have been localized near the exterior of purified virus. The surface proteins can be divided structurally into those with or without transmembrane domains and functionally into those required for morphogenesis and those with known or presumed roles in entry. None of the virus membrane proteins are glycosylated, which has important implications for the derivation of the viral membrane.

Virus cores can be produced in vitro by treatment of virus with a nonionic detergent and reducing agent. About 50 polypeptides, distinct from those in the membrane fraction, were identified in such cores. Of these, about 30 are enzymes of which at least half are directly involved in early mRNA biosynthesis the nonenzymatic proteins may be primarily involved in morphogenesis and structure. 
Fowl pox virus genome is not segmented and contains a single molecule of linear doublestranded DNA that encode for DNA ligase, ATPGTP binding protein, uracil DNA glycosylase, DNA polymerase, DNA topoisomerase, DNA processing factor and replication essential protein kinase (Alfonso et al., 2000). The genome has a GC content of $35 \%$. The genome sequence has termini with cross-linked hairpin ends (i.e. single- stranded loops thus forming one continuous polynucleotide chain). The genome has terminally redundant sequences. The terminally redundant sequences have reiterated inverted terminal sequences which are tandemly repeated; are reiterated internally. The genome sequence is repeated at both ends (Srinivasan et al., 2006).

The current study aimed to recognize the differences between FPV and TPV phenotypically and genetically.

\section{Materials and methods}

Viruses. Fowl pox (FPV) was obtained from Pox department, Veterinary serum and vaccine research institute, Abassia, Cairo, EGYPT. Turkey pox (TPV) virus was isolated and characterized from natural outbreak of pox in turkey in EGYPT (Nakhla and Daoud 2004). The viruses were first propagated onto the chorioallantoic membrane of 9-11 days SPF embryonated chicken eggs, after 5 days of incubation at $37^{\circ} \mathrm{C}$, the chorioalantoic membrane was collected, homogenized in $5 \mathrm{~mL}$ Tris EDTA (TE) buffer (10mM Tris-HCl, $1 \mathrm{mM}$ EDTA $\mathrm{pH}$ 8) and centrifuged briefly at $900 \mathrm{rpm} / 5 \mathrm{~min} / 4^{\circ} \mathrm{C}$ the supernatant was then collected and stored at $20{ }^{\circ} \mathrm{C}$ till used.

Virus purification. Both FP and TP viral suspensi till used.

Dual extraction of the viral DNA and protein. Both viral DNA and viral proteins were extracted from a $0.5 \mathrm{~mL}$ sample of the purified viruses, using Trizol reagent (Life technology cat \# 15596) according to the instruction of the manufacture. First, $0.5 \mathrm{ml}$ of Trizol reagent was added to $0.5 \mathrm{ml}$ of the virus, and incubated at $20^{\circ} \mathrm{C} / 30 \mathrm{~min}$, and then $200 \mu \mathrm{l}$ of chloroform was added and incubated for $3 \mathrm{~min}$ before centrifugation at $14000 \mathrm{rpm} / 15 \mathrm{~min}$ at $4^{\circ} \mathrm{C}$. The upper aqueous phase was completely removed; the DNA in the interphas was precipitated by adding $0.5 \mathrm{ml}$ of absolute ethanol and centrifuged as before.

Extraction and purification of viral DNA. The precipitated DNA from the interphas washed twice with $0.1 \mathrm{M}$ sod. citrate in absolute ethanol and finally redissolved in $50 \mathrm{ul}$ of $8 \mathrm{mM} \mathrm{NaOH}$. The $\mathrm{pH}$ was then adjusted at 8 by adding 115 $\mu 1 / \mathrm{ml}$ HEPES $(0.1 \mathrm{M})$. Two $\mu 1$ of RNAase were then added and incubated at $37^{\circ} \mathrm{C}$ for 1 hour. Purification of the genomic DNA was done using Wizard DNA clean up system (Promega). The DNA was then analysed by agarose gel electrophoresis on $1 \%$ agarose and visualised using the UV. transilluminatore. The size of the genomic DNA was determined using Lambda DNA \Hind III ladder (sibEnzyme cat\# M01) which has bands with molecular size of 23, 9.4, $6.5,4.3,2.3,2.0,0.5$ and $0.12 \mathrm{Kpb}$

Extraction and purification of viral protein. The protein rich supernatant was transferred to another 1.5 microfuge tube and the protein was precipitated with double volume isopropyl alcohol and sedimented by centrifugation as before. Protein was then washed twice with 0.3 M guanidine hydrochloride in $95 \%$ ethanol, centrifuged as before. The protein pellet was then redissolved in $100 \mu$ l of absolute ethanol and stored at $-20^{\circ} \mathrm{C}$ till used.

Determination of protein concentration. The protein concentration was estimated using modified lowery method (Ohnishi and Barr, 1978).

Sodium Dodecyl Sulphate-Polyacrylamide Gel Electrophoresis (SDS-PAGE). Extracted proteins of the purified virus preparations were resolved on discontinuous buffer system composed of $12 \%(\mathrm{w} / \mathrm{v})$ acrylamide separating gel and 4\% stacking gel (Laemmli, 1970). Electrophoresis was carried out at a constant voltage $(100 \mathrm{~V})$ until the bromophenol blue dye moved to the bettom of ithe gel the gels were stained with coomassie brilliant blue for 2 hours and destained overnight. Molecular weight of each protein band was calculated with reference to a standard curve derived from the migration pattern of standard unstained molecular weight markers (Page Ruler, Fermentas cat\# 00018067). Western blotting analysis. The electrophoretic transfer of polyacrylamide gel resolved proteins to the nitrocellulose membrane was carried out by electroblotting as described (Towbin et al., 1979) using BioRad Electro Transfere unit. The unoccupied sites on the nitrocellulose membrane were blocked with blocking buffer (Tris buffered saline TBS, pH 7.2 containing $0.1 \%$ Tween-20, $1 \%(\mathrm{w} / \mathrm{v})$ western blot grade gelatin and $0.05 \%$ Triton X100). The nitrocellulose membrane was then incubated with Anti fowl pox virus antibodies (pox vaccine department VSVRI) 
(1:100 in blocking buffer) at $37^{\circ} \mathrm{C}$ for 1 hour followed by washing three times with TBSTween 20. The membrane was then incubated at $37^{\circ} \mathrm{C}$ for 1 hour in anti-chicken peroxidase labeled dilution of 1:5000 in TBS- tween 20. The membrane was then washed as above and incubated in freshly prepared substrate solution $(10 \mathrm{mg}$ aminoethyle carbazone in $50 \mathrm{ml}$ PBS containing $50 \mu \mathrm{l}$ of $30 \% \mathrm{H}_{2} \mathrm{O}_{2}$ ) for 3-4 min for colour development and visible bands were developed, then the reaction was stopped by washing the membrane with running distilled water. Page Ruler prestained protein ladder (Fermentas cat\#SM0671) was used in this experiment.

PCR amplification. A primer was designed to amplify the lateral terminal repeat gene (Afonso et al., 2000) using NCBI/ Primer-BLAST. The PCR was performed in $50-\mu 1$ reaction mixtures containing $50 \mathrm{mM} \mathrm{KCl}, 10 \mathrm{mM}$ Tris- $\mathrm{HCl}$ (pH8.8), $3 \mathrm{mM} \mathrm{MgCl} 2,200 \mathrm{mM}$ (each) deoxynucleoside triphosphate, $10 \mu \mathrm{l} \mathrm{Q}$ solution (Qiagene) and 2.5 $\mathrm{U}$ of thermostable recombinant Taq DNA polymerase and 50 pmol of the forward primer (5'- TTA-ACC-AGTCTT-ATT-ATT-AA-3') and the reverse primer(5'- TAT-AAA-GGT-GTA-AAT-CCTAAT-TAC-3'). Thermal cycling was performed using $\mathrm{T}$ gradiant, thermal cycler (Biometra , Germany), the parameters for amplification were denaturation at $95{ }^{\circ} \mathrm{C}$ for $3 \mathrm{~min}$ and 40 cycles at $95^{\circ} \mathrm{C}$ for $1 \mathrm{~min}, 54^{\circ} \mathrm{C}$ for $45 \mathrm{sec}$, and $74^{\circ} \mathrm{C}$ for 1 min. A final extension at $72^{\circ} \mathrm{C}$ for $10 \mathrm{~min}$ was also included. The amplicon was electrophoresed on $1 \%$ agarose. $100 \mathrm{pb}$ DNA ladder $(100-1000$ pb ladder, SibEnzyme Cat\# M15) was used to calculate the exact amplicon size

Restriction digestion of the genomic DNA. The genomic DNA of both viruses was digested with both Sau3A (promega cat\# R6191) and Hid III (Fermentas cat \#ER0501), the reaction mixture consists of $10 \mu \mathrm{g}$ of DNA, $1 \mu 1$ of 10 Xrestriction buffer and $5 \mathrm{u}$ of either enzyme. The reaction volume was adjusted to $10 \mu 1$ using nuclease free water and incubated at $37^{\circ} \mathrm{C} / 1 \mathrm{~h}$ followed by inactivation of the enzymes by further incubation at $70^{\circ} \mathrm{C} / 10 \mathrm{~min}$. the reaction was then analyzed by electrophoreses on $1 \%$ agarose.

\section{Results and discussion}

Turkey pox is a slow spreading viral disease causing severe economic losses in terms of meat condemnation, weight loss and drop in egg production in Indian turkey flocks. This disease has an emerging status and it was found that the past literature reveals no information with regards to characterization of this virus. TPV was considered more or less similar to FPV and the available literature reveals the physicochemical characteristics of only FPV and QPV in detail. But now it has been established using cross protection studies that TPV differ from other avipox viruses (Villegas, 1998) and this warrants for the characterization of turkey pox virus isolated from natural outbreak of pox in turkeys. Therefore, in the current study comparison between a turkey poxvirus which was isolated from a natural outbreak of pox in turkeys and the FPV was done on the level of DNA and protein profile.

In order to analyses the phenotypic relatedness of both fowl and turkey pox viruses, 2 step viral purification was done $1^{\text {st }}$ on sucrose gradient then ultra-speed centrifugation followed by total purification of viral DNA and protein using Trizol reagent. The advantage of such method is that this method preserve the integrity of the protein so that the proteins are not subjected to extreme denaturation during the process of separation; in addition to this, it offers complete separation of the protein from the nucleic acids so even the nuclear protein, which is common in pox viruses will be separated and can be analyzed with SDS-PAGE (Chomczynski and Sacchi, 1987).

Avian pox viruses are antigenically and immunologically distinguishable from each other, but varying degree of cross relationship does exist. Attempts have been made to differentiate strains by immunological methods (Singh et al., 2003), antigenic and genomic characterization (Tadese and Reed, 2003) to detect the minor differences among the strains. In the current, study nearly the same protein profile was seen with both FPV and TPV except a single band migrates about $115 \mathrm{KDa}$ in TPV which completely absent in FPV (Table 1, Fig. 1) there were about 7 and 8 clearly visible bands with FPV and TPV respectively. On the other hand, some protein bands although present in both viruses yet the concentration of the band seems different which indicates different in the level of protein expression or different in the amount of mRNA expressed. Western blotting analysis (Fig. 2) revealed a difference in a single band reacted at about $11 \mathrm{KDa}$ with the TPV, although this band was invisible in the SDSPAGE profile. It worth mention that other studies on the fowl pox virus revealed differences in the number of the poly peptide fractionated by SDS-PAGE for example Obijeski 

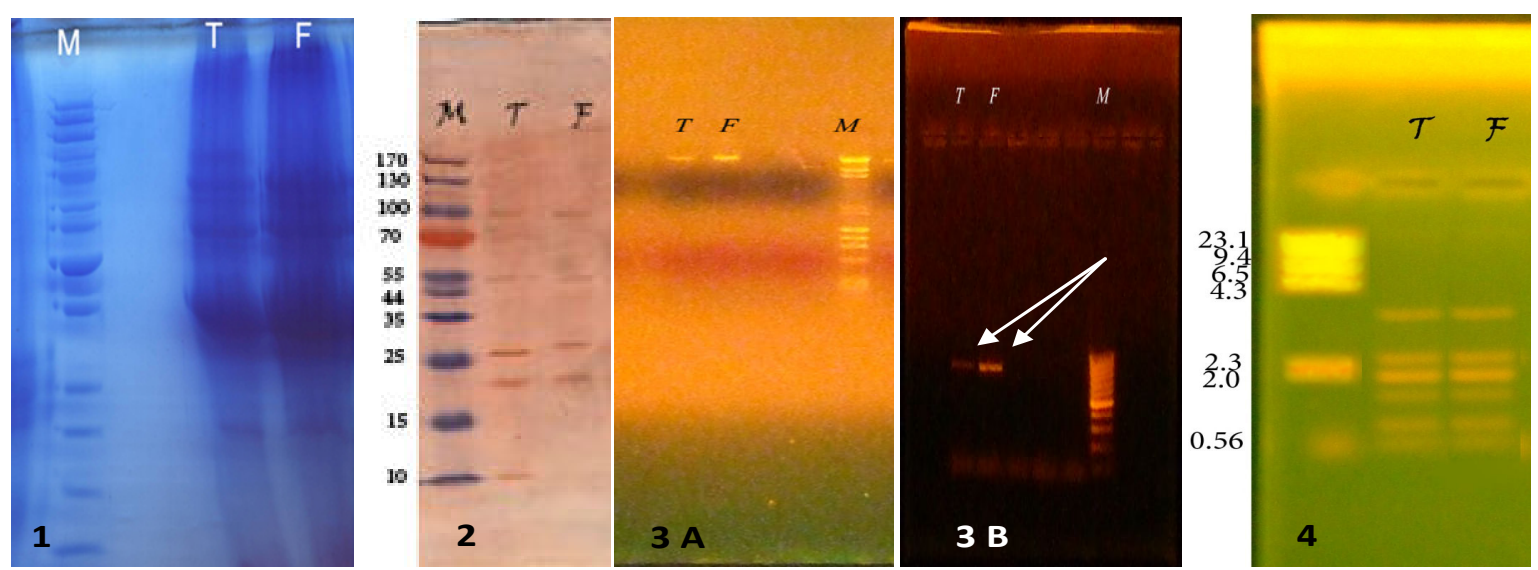

Fig. (1): SDS-PAGE analysis A and western blotting analysis (B) of turkey pox (T) and fowl pox (F) viral proteins. M: Page Ruler protein marker.

Fig. (2): Western blotting analysis of turkey pox (T) and fowl pox (F) viral proteins. M: prestained Page Ruler protein marker. Note the absence of the 10KDa band from the FPV.

Fig. (3): The genomic DNA (A) and The PCR amplification of the gene (B) of turkey pox (T) and fowl pox (F) Note the amplification of a $900 \mathrm{bp}$ band in both turkey and fowl pox viruses. M: DNA marker [lambda Hind III DNA maker (A) or 100 pb ladder (B)]

Fig. (4): Restriction endonuclease analysis of both turkey and Fowl pox virus. Both TPV and FPV gave the same restriction pattern.

Table (1): The analysis results of the protein profile of both fowl and turkey pox viruses.

\begin{tabular}{ccccccc}
\hline \multicolumn{2}{c}{ Molecular weight marker } & \multicolumn{2}{c}{ FPV } & \multicolumn{2}{c}{ TPV } \\
\hline Bands & Band \# & MW & Band \# & MW & Band \# & MW \\
\hline 1 & 1 & 200 & 1 & 210 & 1 & 210 \\
2 & 1 & 150 & & & & \\
3 & 2 & 120 & & & & \\
4 & 3 & 100 & & & 2 & 115 \\
5 & 4 & 25 & 94 & 3 & 94 \\
6 & 5 & 70 & 3 & 82 & 4 & 82 \\
7 & 6 & 60 & 4 & 68 & 5 & 68 \\
8 & 7 & 50 & 5 & 55 & 6 & 55 \\
9 & 8 & 40 & & & & 26 \\
10 & 9 & 30 & 6 & 26 & 7 & 22 \\
11 & 10 & 25 & 7 & 22 & 8 & \\
12 & 11 & 15 & & & & \\
13 & 12 & 10 & 8 & 10 & 9 & 10 \\
14 & 13 & 14 & & & &
\end{tabular}

Table (2): The estimated MW bands and the expected protein nomenclature and function.

\begin{tabular}{lll}
\hline $\begin{array}{l}\text { Bands molecular } \\
\text { weight (KDa) }\end{array}$ & \multicolumn{1}{c}{ Expected protein } & references \\
\hline $\mathbf{9 4}$ & $\begin{array}{l}\text { Early promoter specificity factor associated with } \\
\text { RNA polymerase, packing of transcription complex }\end{array}$ & Ahn et al., (1994) \\
$\mathbf{8 2}$ & Large subunit, heterodimer ATPase enzyme & Baldick et al., (1994) \\
$\mathbf{6 8}$ & Putative metalloprotease & Ansarah and Moss, (2004) \\
$\mathbf{5 5}$ & Poly A polymerase catalytic subunit & Hodel et al., (1996); Latner et al., (2002) \\
$\mathbf{2 6}$ & Myristylated, intra S-S factore & Su et al., (2005) \\
$\mathbf{2 2}$ & Phosphorylated, interacts with A20, transcription, & DeMasi and Traktman, (2000) \\
$\mathbf{1 0}$ & morphogenesis & Mercer and Traktman, (2003) \\
\hline
\end{tabular}


et al., (1973) detect about 28 polypeptides in purified FPV while Mockett et al., (1987) observed about 30 structural polypeptides other studies revealed the presence of 21FPV-coated polypeptides when resolved by ${ }^{35} \mathrm{~S}$ methionine pulse labeling and 57 major structural (Prideaux and Boyle, 1987) such differences in the number of bands may due to difference in the expression profile of both viruses and the purification procedures undertaken.

Some of the protein antigens resolved by SDS were characterized (Table 2), for example, the $94 \mathrm{KDa}$ protein antigen found in both FPV and TPV was found to be Pro-associated protein (RAP94) coded by H4L gene and it is one of the core-associated enzymes and transcription factor (Ahn et al., 1994). The $82 \mathrm{KDa}$ protein was found to be large subunit, heterodimer, DNA binding ATPase enzyme needed for the transcription and coded by the $\mathrm{A} 7 \mathrm{~L}$ gene (Baldick et al., 1994). The 68KDa protein antigen is a protease 2 enzyme called putative metalloprotease coded by G1L gene of Poxviridae (Ansarah and Moss, 2004). Other factors that regulate the viral transcription were characterized such as the $55 \mathrm{KDa}$ protein was found to be a large subunit, poly (A) polymerase stimulatory and transcription factor coded by the J3R gene (Hodel et al., 1996; Latner et al., 2002). The $26 \mathrm{KDa}$ protein is a myristylared intra S-S F9 related factor required for viral morphogenesis and coded by L1R gene ( $\mathrm{Su}$ et al., 2005).

Like other pox viruses both FPV and TPV genomes are composed of a single linear dsDNA molecule with a hairpin loop at each end. Although the overall genomic organization of the FPV appears to be similar to that of the other members of the family Poxviridae, some genomic rearrangements may occur (Schnitzlein et al., 1988). As seen in (Fig. 3A), both viruses gave genomic DNA of about 130kb (Fig 3-A) which is different than the size of the vaccine like strain of FPV which was determined as $288 \mathrm{~kb}$ (Alfonso et al., 2000) or the tissue culture propagated FPV strain FP9 which had a genomic size of $260 \mathrm{~kb}$. These differences in the genomic size may due to the integration of variable length long terminal repeats (LTR) of the reticuloendotheliosis virus (Singh et al., 2005; Tadse and Reed 2003)

Concerning the PCR, Amplification of the conservative sequence of the LTR region of fowl and turkey pox virus gave nearly the same result. A single amplicon migrates about 900bp (Fig3-
B). Based upon restriction endonuclease analysis, both FPV and TPV genome gave the same pattern when digested with Hind III enzyme were using Sau3A no cutting was observed. In this regard, the genomic profile the canary pox, goose pox and quail pox viruses are markedly different from those of the FPV (Kim and tripathy, 2006; Ghildyal et al., 1989; Schnitzlein et al., 1988).

In conclusion, based on the antigenic analysis there were a degree of hetrology between FPV and TPV which could not be proved by the genomic analysis conducted in this study. Further genetic analysis including gene sequencing is needed to examine wither these differences due to genetic alteration or different in gene expression.

\section{References}

Ahn, B. Y.; Gershon, P. D. and Moss, B. (1994): RNApolymerase associated protein RAP94 confers promoter specificity for initiating transcription of vaccinia virus early stage genes. J. Biol. Chem., 269: 7552-7557.

Alfonso, C. L.; Tulman, E. R.; Lu, Z.; Zsak, L.; Kutish, G. F. and Rpck, D. L. (2000): The genome of Fowl pox virus. J. Virol., 74: 3815-3831.

Ansarah, S. C. and Moss, B. (2004): Vaccinia virus G1 protein, a predicted metalloprotease, is essential for morphogenesis of infectious virions but not for cleavage of major core proteins. J. Virol., 78: 6855-6863.

Baldick, C. J.; Cassetti, M. C. and Harris, N. (1994): Ordered assembly of a functional preinitiation transcription complex, containing vaccinia virus early transcription factor and RNA polymerase, on an immobilized template. J. Virol., 68:6052-6056.

Boulanger, D.; Smith, T. and Shinner, M. A. (2000): Morphogenesis and release of fowl pox virus. J. Gen. Virol., 81: 675- 687.

Chomczynski, P. and Sacchi, N. (1987): Links Single-step method of RNA isolation by acid guanidinium thiocyanatephenol-chloroform extraction. Anal Biochem., 162(1):1569.

Chung, C.S.; Chen, C.H. and Ho, M.Y. (2006): Vaccinia virus proteome: identification of proteins in vaccinia virus intracellular mature virion particles. J. Virol., 80:21272140.

Dash, B. B.; Kataria, M. J.; Mazoomdar, S. and Dhama, K. (2003): Avipox virus infections in Turkeys. XXI Conf. Ind. Assosc. Vet. Microbiol. Immunol. Infect. Dis. (IAVMI) and National Seminar on Prospects and Challenges for Better Livestock and Poultry Health Management Employing Conventional and Molecular Approaches, Feb.7-9,

DeMasi, J. and Traktman, P. (2000): Clustered charge-toalanine mutagenesis of the vaccinia virus $\mathrm{H} 5$ gene: isolation of a dominant, temperature-sensitive mutant with a profound defect in morphogenesis. J. Virol., 74:2393-2405. Ghildyal, N.; Schnitzlein, W. M. and Tripathy, D. N. (1989): Genetic and antigenic differences between fowl pox and quail pox viruses. Arch. Virol., 106: 85-92.

Hodel, A. E.; Gershon, P. D. and Shi, X. (1996): The structure of vaccinia protein VP39: a bifunctional enzyme that participates in the modification of both mRNA ends. Cell, 85: 247-256. 
Jensen, O. N.; Houthaeve, T. and Shevchenko, A. (1996): Identification of the major membrane and core proteins of vaccinia virus by two-dimensional electrophoresis. J. Virol., 70:7485-7497.

Joklik, W. K. (1962): The purification of four strains of pox virus. Virology, 18: 9-18.

Kim, T. J. and Tripathy, D. N. (2006): Antigenic and genetic charchterization of an avian pox virus isolated from an endangred hawiian goose (Branta sandvicensis). Avian Dis., 50: 15-21.

Laemmli, U. K. (1970): Cleavage of structural protein during the assemply of the head of bacteriophage T4. Nature, 227: 680-685.

Latner, D. R.; Thompson, J. M. and Gershon, P. D. (2002): The positive transcription elongation factor activity of the vaccinia virus $\mathrm{J} 3$ protein is independent from its methyltransferase and poly (A) polymerase stimulatory functions. Virology, 301: 64-80.

Mercer, J. and Traktman, P. (2003): Investigation of structural and functional motifs within the vaccinia virus A14 phosphoprotein, an essential component of the virion membrane. J. Virol., 77: 8857-8871.

Mockett, A. P.; Southee, D. J.; Tomley, F. M. and Deuter, A. (1987): Fowlpox viris: Its structural proteins and immunogens and the detection of virial- specific antibodies by ELISA. Avian Pathol., 16: 493-504.

Nakhla, O. E. and Daoud, A. M. (2004): Trail for isolation and characterization of pox virus from turkeys. Egypt. J. Agric. Res., 82(2): 869-879.

Obijeski, J. F.; Palmer, E. L.; Gafford, L. G. and Randall, C. C. (1973): Plyacrelamid gel electrophoresis of fowl pox and vaccinia virus proteins. Virology, 51: 512516.

Ohnishi, S. T. and Barr, J. K. (1978): A simplified Method of Quantitating Protein using the Biuret and Phenol Reagents. Anal. Biochem., 86 : 193-200.

Prideaux, C.T. and Boyle, D.B. (1987): Fowl pox virus polypeptides: Sequential appearance and virion associated polypeptides. Arch.Virol., 96: 185-199.

Schnitzlein,W.M.; Ghildyal, N. and Tripathy, D.N. (1988): Genomic and antigenic characterization of Avipoxviruses. Virus Res., 10: 65-76.
Singh, P.; Schnitzlein,W. M. and Tripathy, D. N. (2005): Construction and characterization of a fowl pox virus field isolate whose genome lacks reticuloendotheliosis provirus neucleotide sequences. Avian Dis., 49: 401-408.

Singh, P.; Kim, T. J. and Tripathy, D. N. (2003): Identification and characterization of Fowl Pox virus strains utilizing monoclonal antibodies. J. Vet. Diagn. Invest., 15: 50-54.

Srinivasan,V. Schnitzlein, W. M. and Tripathy (2006): Genetic manipulation of two fowl pox virus late transcriptional regulatory elements influences their ability to direct expression of foreign genes. Virus Res., 116: 8590.

Su, H. P.; Garman, S. C. and Allison, T. J. (2005): The 1.5 1-A structure of the poxvirus L1 protein, a target of potent neutralizing antibodies. Proc. Natl. Acad. Sci., 102: 4240-4245.

Tadese, T. and Reed, W. M. (2003): Use of restriction fragment length polymorphism, immunoblotting and polymerase chain reaction in the differentiation of the avian pox viruses. J. Vet. Diagn. Invest., 15: 141-150.

Towbin, J.; Staehlin, T. and Gordon, J. (1979): Electrophoretic transfer of proteins from polyacrylamide gels to nitrocellulose sheet: Procedure and some applications. Pros. Natl. Acad. Sci. USA, 76:4350-4354.

Tripathy, D. N.; Reed, W. M. (1997): In Diseases of Poultry, $10^{\text {th }}$ ed. Calnek, B.W.; Barnes, H. J.; Beard, C.W.; Mc Dougald, L. R. and Saif, Y. M. eds. Iowa State Univ. Press, Ames. P. 643.

Tripathy, D. N. and Reed, W.M. (1989): Pox. A laboratory manual for the isolation and identification of Avian pathogen, 4th ed. American association of avian pathologists: Kennett Square, PA, 137-143.

Villegas, P. (1998): Titration of biological suspensions. A laboratory manual for the isolation and identification of Avian pathogen, $4^{\text {th }}$ ed. American association of avian pathologists: Kennett Square, PA, 248- 253.

Wakenell, S.; Patricia, D. V. and Diplomate A. C. (2001): Avian pox virus. 'Zoo Technica'World's. Poult. J., 48-55.

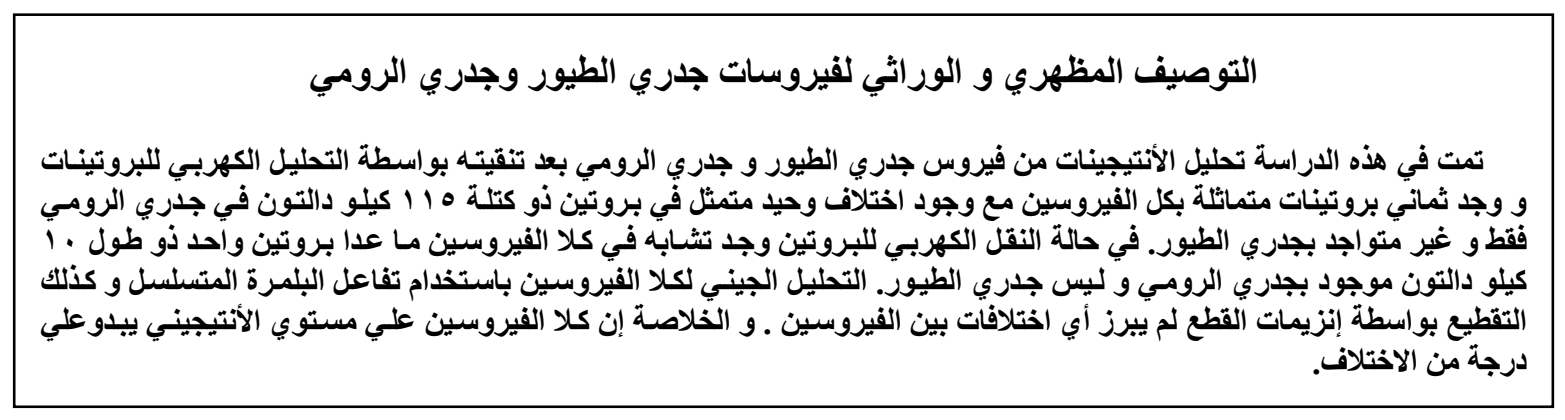

